\title{
VIDEO KARTUN DAN ANIMASI DAPAT MENURUNKAN TINGKAT KECEMASAN PRE OPERASI ANAK USIA PRA SEKOLAH
}

\author{
Ajeng Dwi Retnani ${ }^{1}$, Titin Sutini ${ }^{2}$, Suhendar Sulaeman ${ }^{3}$ \\ 1. Dosen Akper Hermina Manggala Husada Jakata \\ 2,3 Dosen Program Magister Universitas Muhammadiyah Jakarta
}

E-mail: Ajeng.dwi17@yahoo.co.id

\begin{abstract}
Abstrak
Tindakan operasi memerlukan sebuah tindakan keperawatan pre operasi yang merupakan tahapan awal dari keperawatan operatif. Tindakan ini dimulai sejak pasien diterima masuk di ruang terima pasien dan berakhir ketika pasien dipindahkan ke meja operasi untuk dilakukan tindakan pembedahan. Reaksi psikologi dan fisiologi pada prosedur operasi dan proses anestesi yang memungkinkan adanya respon kecemasan, terutama pada anak usia pra sekolah. Anak pra sekolah yang sakit dan harus dirawat di rumah sakit dapat mengalami pengalaman yang tidak menyenangkan dan menimbulkan kecemasan. Mereka cenderung menolak perawatan dan pengobatan yang sedang dijalani sehingga menyebabkan terjadinya delay terhadap beberapa tindakan termasuk operasi. Tujuan penelitian ini ialah menganalisis pengaruh video kartun terhadap penurunan tingkat kecemasan pre operasi pada anak usia pra sekolah. Metode penelitian ini menggunakan quasi eksperimental dengan pendekatan pre and post-test without control. Teknik pengambilan sampel menggunakan purposive sampling dengan sampel 20 anak yang dibagi menjadi 2 kelompok. Instrumen penelitian ini menggunakan kuesioner kecemasan HARS. Analisis data menggunakan paired t-test. Hasil penelitian menunjukkan bahwa penurunan tingkat kecemasan pre operasi pada anak usia pra sekolah setelah diberikan intervensi video kartun sebesar 4,20, setelah diberikan intervensi video animasi sebesar 4,70. Hasil penelitian juga didapatkan $p$ value > 0,000 , yang artinya adanya pengaruh video kartun dan video animasi terhadap penurunan tingkat kecemasan pre operasi pada anak usia pra sekolah. Saran yang dapat peneliti berikan ialah perawat dapat memberikan intervensi pemberian video animasi untuk meminimalkan kecemasan pre operasi pada anak usia pra sekolah.
\end{abstract}

Kata kunci: video kartun, animasi, kecemasan, pre operasi.

\begin{abstract}
Surgery requires a preoperative nursing action which is the initial stage of operative nursing, which starts from the time the patient is admitted into the patient's reception room and ends when the patient is transferred to the operating table for surgery. Psychological and physiological reactions to surgical procedures and anesthetic processes that allow for an anxiety response, especially in pre-school-aged children. Preschoolers who are sick and have to be hospitalized can experience unpleasant experiences and cause anxiety. They tend to refuse treatment and treatment that is being undertaken, causing delays to some actions including surgery. The purpose of this study was to analyze the effect of cartoon videos on reducing preoperative anxiety levels in preschool age children. This research method uses quasi-experimental with a pre and post-test approach with out control. The sampling technique used purposive sampling with a sample of 20 children who were divided into 2 groups. This research instrument uses the HARS anxiety questionnaire. Data analysis using paired t-test. The results showed that the decrease in preoperative anxiety levels in pre-school children after being given a cartoon video intervention by 4.20, after being given an animated video intervention by 4.70. The results of the study also obtained $p$ value> 0,000, which means the influence of cartoon videos and animated videos on reducing preoperative anxiety levels in pre-school age children. Suggestions that researchers can give are nurses can provide animation video interventions to minimize preoperative anxiety in pre-school age children.
\end{abstract}

Keywords: cartoon video, animated video, anxiety, and preoperative

\section{PENDAHULUAN}

Anak usia pra sekolah memiliki resiko besar untuk mengalami masalah kesehatan jika dikaitkan dengan respon imun dan kekuatan pertahanan dirinya yang belum optimal (Papalia, et al, 2009). Alini (2017) juga menyatakan bahwa pada masa usia pra sekolah aktifitas anak yang meningkat 
menyebabkan anak kelelahan dan menjadikan anak rentan terhadap penyakit akibat daya tahan tubuh yang lemah sehingga anak diharuskan menjalani hospitalisasi, termasuk operasi. Lebih dari 230 juta operasi mayor dilakukan setiap tahun di dunia yang menyebabkan keadaan pasien saat operasi akan lemah, meningkatkan komplikasi setelah operasi dilakukan bahkan dapat menyebabkan kematian (Priece \& Moreno, 2012).

Tindakan operasi memerlukan sebuah tindakan keperawatan pre operasi yang merupakan tahapan awal dari keperawatan operatif yang dimulai sejak pasien diterima masuk di ruang terima pasien dan berakhir ketika pasien dipindahkan ke meja operasi untuk dilakukan tindakan pembedahan (Wijayanti, 2011). Salah satu persiapan pre operasi ialah persiapan mental/psikis. Persiapan mental ini merupakan hal yang tidak kalah pentingnya dalam proses persiapan operasi karena mental pasien yang tidak siap atau labil dapat berpengaruh terhadap kondisi fisiknya dan kelancaran proses operasi. Perawat perlu mengkaji mekanisme koping pasien dalam menghadapi stres, dimana tindakan operasi merupakan salah satu keadaan pemicu kecemasan dan stress pada pasien terutama pada pasien anak (Sjamsuhidajat \& De Jong, 2010).
Reaksi psikologi dan fisiologi pada prosedur operasi dan proses anestesi yang memungkinkan adanya respon kecemasan (Lewis, et al, 2011). Kementrian Kesehatan RI (2011) menyebutkan bahwa sekitar 50\%-70\% dari anak-anak yang menjalani operasi mengalami kecemasan dan kesusahan yang parah sebelum operasi (Alini, 2017).

Kecemasan yang dialami anak usia pra sekolah bila tidak segera ditangani akan mengakibatkan tubuh menghasilkan hormon yang menyebabkan kerusakan pada seluruh tubuh termasuk menurunkan kemampuan sistem imun (Putra, 2011). Anak yang mengalami cemas cenderung menolak perawatan dan pengobatan yang sedang dijalani (tidak kooperatif) sehingga menyebabkan terjadinya delay terhadap tindakan operasi yang akan dilakukan.

Hasil studi pendahuluan di ruang rawat inap RS Islam A. Yani Surabaya melalui wawancara dengan perawat ruang anak diketahui bahwa 4 dari 5 perawat ruangan mengalami kesulitan dalam menghadapi pasien anak yang akan menjalani operasi. Anak cenderung melakukan penolakan saat perawat akan mengukur tanda-tanda vital, menginjeksi obat atau mengganti cairan infus. Hal yang sama juga dikemukakan oleh perawat bedah RS Islam A. Yani Surabaya yaitu untuk 
melakukan tindakan operasi pada pasien anak cenderung membutuhkan waktu yang sedikit lebih lama daripada pasien dewasa. Mereka perlu menunggu hingga anak berhenti menangis dan mau untuk didekati perawat. Kecemasan ini memberikan dampak negatif jangka panjang pada anakanak terhadap tindakan medis di kemudian hari.

Kecemasan pre operasi pada anak usia pra sekolah ini perlu diatasi dengan mengurangi ketakutan mereka terhadap ruang operasi, tindakan yang akan dilakukan pada dirinya dan orang-orang yang terlibat di dalamnya. Persiapan psikologis sebagai hak dasar anak-anak yang menjalani operasi tidak boleh dilupakan dan diabaikan karena proses persiapan ini merupakan tugas dan tanggung jawab perawat (Majzoobi, et al, 2013). Kecemasan ini perlu diatasi dengan melakukan persiapan psikologis berbasis caring seperti teori model keperawatan yang digambarkan oleh Kristen Swanson dalam teori caring.

Terdapat beberapa macam persiapan psikologis guna mengurangi kecemasan pre operasi pada anak pra sekolah, salah satunya ialah teknik non-farmakologi, seperti kehadiran orang tua, musik, akupunktur, terapi bermain, bermain dengan mainan yang sudah dikenal, dan menonton kartun (Potter \& Perry, 2012). Amerika Academy of Pediatrics merekomendasikan beberapa cara untuk mengurangi kecemasan dan membantu anak-anak mengatasi stres rawat inap dan operasi, yaitu dengan pemberian informasi, pendidikan kesehatan, dan membina hubungan saling percaya dengan anakanak dan orang tua mereka dengan menggunakan beberapa alat, seperti gambar, diagram, boneka, orientasi tour area operasi atau ruang perawatan (Brown, 2012).

Berdasarkan beberapa intervensi nonfarmakologi guna menurunkan tingkat kecemasan anak usia pra sekolah yang sudah dijelaskan di atas, maka peneliti tertarik untuk mengukur keefektifan video kartun dan video animasi terhadap penurunan tingkat kecemasan pre operasi pada anak usia pra sekolah di RS Islam A. Yani Surabaya.

\section{METODE PENELITIAN}

Penelitian ini menggunakan desain quasi eksperimental dengan pendekatan pre and post-test without control. Populasi yang digunakan dalam penelitian ini adalah anak usia pra sekolah yang akan menjalani operasi di RS Islam A. Yani Surabaya. Teknik pengambilan sampel menggunakan purposive sampling. Sampel dalam penelitian ini ialah anak yang akan 
menjalani operasi di RS Islam A. Yani Surabaya yakni sebanyak 20 anak yang dibagi menjadi 2 kelompok. Instrumen yang digunakan ialah kuesioner HARS untuk mengukur kecemasan pre operasi pada anak usia pra sekolah.

Kriteria inklusi pada penelitian ini diantaranya anak usia 3-5 tahun, anak menjalani rawat inap di rumah sakit minimal 1 hari sebelum jadwal operasi, anak yang akan menjalani operasi sedang dan orang tua bersedia anak menjadi responden. Untuk kriteria ekslusi pada penelitian ini adalah anak yang dilakukan operasi cito, anak yang memiliki kelainan konginetal dan penyakit lainnya seperti sindrom down, tuna netra, dan sebagainya, serta kondisi anak sangat lemah sehingga tidak memungkinkan untuk menonton video.

Sebelum dilakukan proses pengambilan data, orang tua calon responden diberikan informasi tentang penelitian yang akan dilakukan, keuntungan dan dampak yang mungkin dapat ditimbulkan selama proses penelitian, bila orang tua calon responden menyetujuinya maka dilanjutkan dengan pengisian lembar persetujuan menjadi responden. Setelah mendapatkan persetujuan dari orang tua, akan dilakukan pengukuran kecemasan anak sebelum intervensi menggunakan skala HARS 40 menit sebelum anak dibawa ke ruang operasi.

Pada kelompok video kartun, anak diberi kesempatan memilih salah satu kartun (bobo boy, tayo the little bus dan marsha and the bear) kemudian dilakukan pemutaran video kartun selama 15 menit. Pada kelompok video animasi, dilakukan pemutaran video animasi selama 15 menit. Setelah pemutaran video dilakukan pengukuran kecemasan anak setelah dilakukan intervensi menggunakan skala HARS 5 menit sebelum anak masuk ke ruang operasi.

HASIL

Tabel 1. Distribusi frekuensi responden di RS Islam A. Yani Surabaya $(n=20)$

\begin{tabular}{|c|c|c|c|}
\hline No. & Variabel & Frekuensi & $\begin{array}{c}\text { Persentase } \\
(\%)\end{array}$ \\
\hline \multirow[t]{6}{*}{1.} & $\begin{array}{l}\text { Jenis Kelamin } \\
-\quad \text { Video kartun }\end{array}$ & & \\
\hline & a. Laki-laki & 6 & 60 \\
\hline & b. Perempuan & 4 & 40 \\
\hline & - Video animasi & & \\
\hline & a. Laki-laki & 5 & 50 \\
\hline & b. Perempuan & 5 & 50 \\
\hline \multirow[t]{9}{*}{2.} & Riwayat operasi & & \\
\hline & - Video kartun & & \\
\hline & a. 0 & 10 & 100 \\
\hline & b. 1 & 0 & 0 \\
\hline & c. $>1$ & 0 & 0 \\
\hline & - Video animasi & & \\
\hline & a. 0 & 10 & 100 \\
\hline & b. 1 & 0 & 0 \\
\hline & c. $>1$ & 0 & 0 \\
\hline
\end{tabular}

Sumber : data primer, 2019

Tabel 1 menunjukkan bahwa sebagian besar anak berjenis kelamin laki-laki. Pada data riwayat operasi, seluruh responden belum memiliki riwayat operasi sebelumnya yang artinya semua responden baru pertama kali menjalani operasi. 
Tabel 2. Distribusi frekuensi tingkat kecemasan sebelum intervensi berdasarkan jenis kelamin $(\mathrm{n}=20)$

\begin{tabular}{|c|c|c|c|c|c|c|}
\hline \multirow{3}{*}{$\begin{array}{c}\text { Jenis } \\
\text { kelamin } \\
\text { responden }\end{array}$} & \multicolumn{3}{|c|}{ Kecemasan responden } & \multirow{2}{*}{\multicolumn{2}{|c|}{ Total }} & \\
\hline & \multicolumn{2}{|c|}{$\begin{array}{c}\text { Kecemasan } \\
\text { sedang }\end{array}$} & \multirow{2}{*}{$\begin{array}{c}\begin{array}{c}\text { Kecemasan } \\
\text { Berat }\end{array} \\
\text { F }\end{array}$} & & & \\
\hline & $\mathbf{F}$ & $\%$ & & $\%$ & $\mathbf{N}$ & $\%$ \\
\hline Laki-laki & 11 & 100 & 0 & 0 & 11 & $\begin{array}{c}10 \\
0\end{array}$ \\
\hline Perempuan & 6 & 66,7 & 3 & $\begin{array}{l}3 \\
3 \\
3\end{array}$ & 9 & $\begin{array}{c}10 \\
0\end{array}$ \\
\hline Total & 17 & $85 \%$ & 3 & $\begin{array}{l}1 \\
5\end{array}$ & 20 & $\begin{array}{c}10 \\
0\end{array}$ \\
\hline
\end{tabular}

Sumber : data primer, 2019

Tabel 2 menunjukkan terdapat 11 anak berjenis kelamin laki-laki termasuk dalam kecemasan sedang. Pada anak yang berjenis kelamin perempuan, terdapat 6 anak termasuk dalam kecemasan sedang dan 3 anak termasuk dalam kecemasan berat.

Tabel 3. Perbedaan rata-rata tingkat kecemasan pre operasi pada anak usia pra sekolah sebelum dan setelah intervensi menonton video kartun dan video animasi di RS Islam A. Yani Surabaya $(n=20)$

\begin{tabular}{lccccc}
\hline \multicolumn{1}{c}{ Variabel } & Mean & SD & $\mathbf{9 5 \%}$ CI & $\begin{array}{c}\boldsymbol{p} \\
\text { value }\end{array}$ & $\mathbf{n}$ \\
\hline a.Menonton video kartun & & & & \\
\hline $\begin{array}{l}\text { Tingkat kecemasan } \\
\text { sebelum }\end{array}$ & 24,70 & 2,111 & $3,258-$ & 0,000 & 10 \\
& 20,50 & 2,506 & 5,142 & & \\
$\begin{array}{l}\text { Tingkat kecemasan } \\
\text { setelah }\end{array}$ & $-4,20$ & & & & \\
Selisih & & & & & \\
\hline b. Menonton video animasi & & & & \\
\hline $\begin{array}{l}\text { Tingkat kecemasan } \\
\text { sebelum }\end{array}$ & 24,40 & 1,767 & $3,529-$ & 0,000 & 10 \\
Tingkat kecemasan & 19,70 & 2,058 & 5,871 & & \\
setelah & $-4,70$ & & & & \\
Selisih & & & & & \\
\hline
\end{tabular}

Berdasarkan tabel 3 menunjukkan bahwa pada kelompok anak yang diberikan intervensi menonton video kartun mengalami penurunan tingkat kecemasan pre operasi sebesar 4,20. Hasil uji statistik didapatkan nilai $p$ value $=0,000$ dengan derajat kepercayaan $95 \% \quad(3,258-5,142)$, sehingga dapat disimpulkan bahwa ada perbedaan antara tingkat kecemasan pre operasi pada anak sebelum dan setelah diberikan intervensi menonton video kartun. Maka, pemberian video kartun dalam menurunkan tingkat kecemasan pre operasi pada anak usia pra sekolah.

Tabel 3 juga menunjukkan bahwa pada kelompok yang diberikan intervensi menonton video animasi terjadi penurunan tingkat kecemasan pre operasi sebesar 4,70. Hasil uji statistik didapatkan nilai $p$ value $=0,000$ dengan derajat kepercayaan $95 \% \quad(3,529-5,871)$, sehingga dapat disimpulkan bahwa ada perbedaan antara tingkat kecemasan pre operasi anak sebelum dan setelah diberikan intervensi menonton video animasi.

Berdasarkan penjelasan di atas, dapat diketahui bahwa penurunan tingkat kecemasan pre operasi anak setelah diberikan video kartun lebih kecil daripada penurunan tingkat kecemasan pre operasi anak setelah diberikan video animasi. Maka, pemberian video animasi lebih efektif daripada video kartun dalam menurunkan tingkat kecemasan pre operasi pada anak usia pra sekolah. 


\section{PEMBAHASAN}

\section{Jenis kelamin}

Hasil analisis didapatkan bahwa anak lakilaki yang termasuk dalam kecemasan sedang ialah sebanyak 11 anak dan tidak ada yang termasuk dalam kecemasan berat, sedangkan pada anak perempuan yang termasuk dalam kecemasan sedang ialah sebanyak 6 anak dan yang termasuk dalam kecemasan berat sebanyak 3 anak. Potter \& Perry (2012) yang menyebutkan bahwa salah satu faktor yang mempengaruhi kecemasan ialah jenis kelamin. Kecemasan lebih sering terjadi pada anak perempuan dibandingkan anak laki-laki. Hal ini karena laki-laki lebih aktif dan eksploratif sedangkan perempuan lebih sensitif dan banyak menggunakan perasaan. Pada perempuan juga lebih mudah dipengaruhi oleh tekanan-tekanan lingkungan daripada laki-laki, kurang sabar dan mudah menggunakan air mata.

\section{Riwayat operasi}

Hubungan riwayat operasi dengan tingkat kecemasan pre operasi anak usia pra sekolah dalam penelitian ini tidak dapat dianalisis karena semua responden belum ada riwayat operasi sebelumny. Maka, perlu adanya penelitian yang menggunakan responden yang variatif. Menurut Hockberry \& Wilson (2010) ialah anak yang mempunyai pengalaman sebelumnya akan mulai membentuk respon koping dibandingkan dengan anak yang belum mempunyai pengalaman. Hal ini juga didukung oleh Supartini (2013) yang menjelaskan bahwa anak yang baru mengalami perawatan di rumah sakit akan berisiko menimbulkan perasaan cemas yang ditimbulkan baik oleh anak maupun orang tua.

Berbagai kejadian dapat menimbulkan dampak atraumatik terutama pada anak yang baru pertama kali mengalami perawatan di rumah sakit, salah satunya karena adanya pengalaman interaksi yang tidak baik dengan petugas kesehatan. Kaplan \& Sadock (2010) juga menyebutkan bahwa tingkat kecemasan anak yang akan menjalani operasi pertama kali akan berbeda dengan anak yang sudah pernah menjalani operasi. Hal ini disebabkan karena anak yang pernah dirawat sebelumnya di rumah sakit yang sama akan merasa lebih terbiasa dibandingkan dengan yang baru pertama kali dirawat serta anak akan merespon sakitnya dengan lebih positif.

\section{Pengaruh video kartun terhadap penurunan tingkat kecemasan pre operasi pada anak usia pra sekolah}

Hasil penelitian menunjukkan bahwa ada perbedaan tingkat kecemasan anak sebelum dan setelah diberikan intervensi video kartun $(p$ value $=0,000)$ dengan 
penurunan nilai rata-rata tingkat kecemasan pre operasi anak sebesar 4,20. Video kartun cocok digunakan untuk mendistraksi/mengalihkan rasa cemas anak menjelang operasi (Noorlaila, 2010). Teknik distraksi yang dapat dilakukan untuk mengatasi kecemasan anak yaitu melibatkan anak dalam permainan, karena bermain merupakan salah satu alat komunikasi yang natural bagi anak-anak (Suryanti et al, 2011). Penelitian oleh Lee (2012) menyatakan bahwa metode menonton kartun sangat efektif untuk mengurangi kecemasan pra operasi. Intervensi ini merupakan metode yang murah, mudah dikelola, dan komprehensif untuk mengurangi kecemasan dalam populasi bedah pediatrik.

\section{Pengaruh video animasi terhadap penurunan tingkat kecemasan pre operasi pada anak usia pra sekolah}

Hasil penelitian menunjukkan bahwa ada perbedaan tingkat kecemasan anak sebelum dan setelah diberikan intervensi video animasi $(p$ value $=0,000)$ dengan penurunan tingkat kecemasan pre operasi anak sebesar 4,70. Penurunan tingkat kecemasan pre operasi menggunakan video animasi ini lebih besar daripada pemberian video kartun.

Kecemasan pada anak timbul karena menghadapi sesuatu/lingkungan yang baru dan belum pernah ditemui sebelumnya, serta ketidaknyamanan/ketakutan terhadap sesuatu karena merasa bahaya dan menyakitkan (Townsend, 2009 dalam Suprobo, 2017). Pada anak usia pra sekolah, ia akan beranggapan bahwa saat dipindahkan ke ruang operasi hal tersebut merupakan sebuah hukuman baginya sehingga timbul perasaan malu dan bersalah, merasa dipisahkan, merasa tidak aman dan kemandiriannya terhambat (Hockberry \& Wilson, 2010).

Salah satu cara yang dapat digunakan perawat untuk mengurangi kecemasan pre operasi anak ialah dengan pemberian informasi menggunakan beberapa alat, seperti gambar, diagram, boneka, orientasi tour area operasi atau ruang perawatan (Brown, 2012). Tour area operasi yang dimodifikasi dengan menggunakan media video animasi dapat memudahkan anak usia pra sekolah yang memiliki daya imajinasi tinggi untuk mendapatkan informasi ringan berbasis menyenangkan, sekaligus menurunkan kecemasan pre operasinya.

\section{KESIMPULAN}

Berdasarkan hasil penelitian dapat disimpulkan bahwa terdapat perbedaan rata-rata tingkat kecemasan pre operasi anak sebelum dan setelah diberikan video kartun $(p$ value $=0,000$, selisih $=4,20)$ dan 
intervensi video animasi ( $p$ value $=0,000$, selisih $=4,70)$.

\section{SARAN}

Perawat diharapkan dapat menerapkan pemberian video animasi berupa video tour area operasi untuk anak usia pra sekolah yang akan menjalani operasi. Intervensi ini merupakan salah satu tindakan atraumatic care berbasis caring. Bagi peneliti selanjutnya diharapkan dapat mempertimbangkan jumlah sampel yang lebih besar, karakteristik responden yang lebih variatif dari sisi pengalaman operasi sebelumnya, dan penggunaan instrumen lain untuk mengukur tingkat kecemasan pada anak.

\section{UCAPAN TERIMA KASIH}

Peneliti mengucapkan terimakasih kepada responden (pasien anak) di RS Islam A.Yani Surabaya dan keluarga yang telah berpartisipasi dalam penelitian ini.

\section{DAFTAR PUSTAKA}

Alini, A. (2017). Pengaruh terapi bermain plastisin (playdough) terhadap kecemasan anak usia pra sekolah (36 tahun) yang mengalami hospitalisasi di ruang perawatan anak RSUD Bangkinang. Jurnal Ilmu Kedokteran, 1(2), 4-7.

Astarani, K. (2017). Hospitalisasi \& tempat bermain pada anak. Adjie Media Nusantara, Nganjuk.
Brown, J. (2012). Effects of group medical play on reducing stress, fear, and anxiety in children. Master's thesis The University of Alabama.

Hockenberry, J. M. \& Wilson D. (2010). Wong's essentials of pediatric nursing. Mosby Elsevier, Philadelphia.

Kaplan, H.I. \& Sadock B.J. 2010. Retardasi Mental dalam Sinopsis Psikiatri. Tangerang: Binarupa Aksara.

Lee, J., Jihye L.S., Hyungsun L. S., \& JunRae L. (2012). Cartoon distraction alleviates anxiety in children during induction of anesthesia. International anesthesia research society, 115(5), 1168-1173.

Mudatsir. (2010). Spiritual emotional freedom technique dan nyeri pasien pasca operasi fraktur femur. Jurnal Terpadu Ilmu Kesehatan, 45-49.

Noorlaila, I. (2010). Panduan lengkap mengajar paud. Pinus book publisher, Yogyakarta.

Papalia, Diane E., Sally W. Old, \& Ruth D. Feldman. (2010). Human development (Psikologi Perkembangan) Bag. I-IV. Salemba Humanika, Jakarta.

Potter \& Perry. (2012). Fundamental of nursing. Salemba Medika, Jakarta.

Priece \& Moreno. (2012). At a glance ilmu bedah. Edisi Ketiga. EGC, Jakarta.

Putra, S.T. (2011). Psikoneuroimunologi kedokteran. AUP, Surabaya.

Sjamsuhidajat, R., \& De jong W. (2010). Buku ajar ilmu bedah. EGC, Jakarta. 
Supartini, Y. (2013). Konsep dasar keperawatan anak. EGC, Jakarta.

Suprobo, G.N.P. (2017). Pengaruh terapi audio visual terhadap penurunan tingkat kecemasan pada anak preschool yang dilakukan pemasangan infus di UGD RSUD Wates. Jurnal Keperawatan.

Suryanti, Sodikin, \& Yulistiani. (2011). Pengaruh terapi bermain mewarnai dan origami terhadap tingkat kecemasan sebagai efek hospitalisasi pada anak usia pra sekolah di RSUD Dr. R. Goetheng Tarunadibrata Purbalingga. Jurnal kesehatan.

Wijayanti, R. (2011). Pengaruh pemberian terapi murottal terhadap tingkat kecemasan pada pasien pre operasi di ruang rawat inap kelas III RS PKU Muhammadiyah Yogyakarta. Jurnal STIKES. 